Bangladesh J. Bot. 44(2): 293-298, 2015 (June)

\title{
PHYTOREMEDIATION OF SOIL CONTAMINATED WITH ZINC AND LEAD BY USING ZEA MAYS L.
}

\author{
Abdel-Haleem Mohammed Ahmed and Hanan Helmy latif \\ Department of Biological and Geological Science, Faculty of Education, \\ Ain Shams University, Cairo, Egypt
}

Key words: Phytoremediation, Heavy metal, Zea mays, Protein

\begin{abstract}
This study was carried out to investigate the potential of Corn (Zea mays) for phytoremediation of soil contaminated with lead (Pb) and zinc (Zn). The Zea mays L. cv. Giza 2, Hordeum vulgare cv. Giza 123 and Lupinus termis cv. Giza 1 species were planted in poted soil contaminated with lead and zinc. Zea mays was also cultivated with Hordeum and Lupinus treated with lead and zinc. The results showed that growth decreased by (16.7, 48.63 and 23.56\%), photosynthetic pigments decreased by $(10.18,22.38$ and 10.9\%) and total-N decreased by (30.0, 27.27 and 13.64\%) in Zea, Hordeum and Lupinus, respectively as compared to control. Proteins profile in shoots of tested plants revealed qualitative and quantitative changes. Co-cultivated Zea with Hordeum and Lupinus treated with lead and zinc improvement all parameters. The evidences provided by this experiment indicated that Corn acts as an effective accumulator to zinc and lead .
\end{abstract}

\section{Introduction}

High concentrations of heavy metals in soil may affect crop growth, as these metals interfere with metabolic functions in plants, including physiological and biochemical processes. The most dangerous heavy metals are Pb, Hg, As, Cd, Sn, Cr, Zn and Cu (Wright 2007 and Gosh 2010). $\mathrm{Zn} 2+$ at high levels leads to chlorosis in young leaves, inhibits photosynthesis at various steps and decreases the growth and metabolic activity in various plant species (Vaillant et al., 2005). Moreover, the reduction in nitrogen content under high zinc treatment had been shown by Sivasankar et al. (2012). Pb2+ inhibits some of metabolic activities in the plant (Hamid et al., 2010). Eun et al. (2000) showed that a reduction in growth when exposed to increased levels of $\mathrm{Pb}$ resulted in the inhibition of cellular processes within root tips. In addition, responses of plants to $\mathrm{Pb}$ exposure include a decrease in root elongation and biomass (Fargasova 2001). Also photosynthesis is adversely affected by increasing levels of $\mathrm{Pb}$ through the distortion of chloroplasts, inhibition of electron transport, reduction of chlorophyll synthesis, disruption of Calvin's cycle enzymes and a reduction in carbon dioxide intake (Sharma and Dubey 2005). Saygideger et al. 2004, showed that there was a decrease in total-N content of Typha latifolia in parallel to increased $\mathrm{Pb}$ concentration. Plants that accumulate metals to high concentrations are sometimes referred to as "hyperaccumulators" (Visoottiviseth et al. 2002). Corn (Zea mays) is known to be a good accumulator of contaminants (Molgarzata and Andzej 2005). The maize plant has been even shown to accumulate certain heavy metals such as Pb (Pereira et al. 2007). The aim of this study is to assess the effect of lead and zinc on physiological and biochemical attributes of Zea mays L. cv. Giza 2, Hordeum vulgaris cv. Giza 123 and Lupinus termis cv. Giza 1, and the potential of Zea mays for phytoremediation of lead and zinc.

\section{Material and Methods}

Pure strains of Zea mays L. cv. Giza 2, Lupinus termis cv. Giza 1 and Hordeum vulgare cv. Giza 123 were obtained from Egyptian Agricultural Organization, Ministry of Agriculture, Egypt.

*Author for correspondence: <hananhelmy70@yahoo.com>) 
The experiment was conducted at the Faculty of Education, Ain Shams University. Homozygous seeds were sterilized by $0.01 \mathrm{M} \mathrm{HgCl} 2$ solution for three minutes, washed thoroughly with distilled water and eight seeds were planted in each pot (3.5 kg/pot). The $1 \mathrm{st}$ group included two subgroups each contained Zea plants, first irrigated with tap water all through and the other Zea plants were irrigated after 10 days from sowing with aqueous solutions $100 \mathrm{mg} / \mathrm{l} \mathrm{Zn}+100 \mathrm{mg} / \mathrm{l}$ $\mathrm{Pb}$. The 2nd group included three subgroups each contained Lupinus plants, the third subgroup contained Zea cultivated with Lupinus having 4 seeds each of Zea and Lupinus. The 3rd group included three subgroups, each contained Hordeum plants, the third subgroup contained Zea cultivated with Hordeum each pot containing 4 seeds of each of Zea and Hordeum. All pots were kept inside an open air wire house exposed to normal day length and natural illumination. Growth measurements were carried out at 32 days after sowing. Ten replicates were used for growth and triplicates for pigments, total- $\mathrm{N}$ and proline. Other samples were taken for the determination of certain mineral ions and protein.

The chlorophylls (Metzner et al. 1965) and total $-\mathrm{N}$ (Pirie 1955) as described by Hassanein (1977). $\mathrm{Pb}$ and $\mathrm{Zn}$ were determined in shoot and root using ICP inductively coupled Argon plasma, icap 6500 Duo using the method of AACC (1983) and that of proline by Bates et al. (1973). SDS-polyacrylamide gel electrophoresis (SDS-PAGE) was performed for total soluble protein (Laemmli (1970) as modified by Studier (1973). The obtained data were statistically following SAS- Programme (1982).

\section{Results and Discussion}

$\mathrm{Pb}$ and $\mathrm{Zn}$ stress caused a significant decrease in growth biomass of Zea, Lupinus and Hordeum as compared to control (Table 1). On the other hand, Zea plant cultivated with Lupinus and Hordeum plants decreased the inhibition of the growth characters in both plants under the $\mathrm{Pb}$ and $\mathrm{Zn}$ stress. It has been reported that $\mathrm{Pb}$ reduces root growth by restricting cell division (Eun et al. 2000) and cell elongation (Malkowski et al. 2002). Zeng-Bin Luo et al. 2010) also reported that high levels of $\mathrm{Zn}$ inhibited growth of Jatropha seedlings by interfering with normal cellular metabolic events and inducing visible injuries and physiological disorder. Moreover, the first visible damage due to excessive zinc was on root growth because of reduction in cell division (Prasad et al. 1999). The effects of $\mathrm{Zn}^{2}+$ and $\mathrm{Pb}^{2}+$ in combination leading to the injurious effects of the plants investigated which may suggest a synergistic effect between $\mathrm{Zn}^{2+}$ and $\mathrm{Pb}^{2+}$ on seedlings growth. Similar inhibitory effects in co-presence of metals have also been observed in other plant species (January et al. 2008, Israr et al. 2011). Guo et al. (2007) showed that the synergistic effects of heavy metal burdens are significantly more toxic than the individual heavy metal exposure.

Changes in chlorophyll a and b, carotenoids and total pigment contents in leaves of Zea, Lupinus and Hordeum plants illustrated significant decrease as compared to control in response to $\mathrm{Pb}$ and $\mathrm{Zn}$ treatments (Table 1). In addition, Zea plant cultivated with Lupinus and Hordeum increased the photosynthetic pigments in both plants under the $\mathrm{Pb}$ and $\mathrm{Zn}$ stress. Similar decrease in chlorophyll content under heavy metal stress was reported earlier in Zea mays, Quercus palustrus and Acer rubrum (Siedlecka and Krupa 1996).

$\mathrm{Pb}$ and $\mathrm{Zn}$ contents in roots and shoots of all plants in the test showed significant increases under stress with heavy metals (Table 2). Accumulation of $\mathrm{Pb}$ and $\mathrm{Zn}$ recorded in Zea plant was more than Lupinus and Hordeum plants. Total nitrogen content in shoots of Zea, Lupinus and Hordeum plants treated with $\mathrm{Pb}$ and $\mathrm{Zn}$ was significantly lower than their control ones. In contrast, the content of total nitrogen increased in treated plants when cultivated with Zea mays, which may refer to the decrease in proteolytic activity. This result is similar to Saadet et al. (2004), who 
reported a decrease in total $\mathrm{N}$ content of $T$. latifolia in parallel to increased $\mathrm{Pb}$ concentrations. Also, Godbold and Kettner (1991a) revealed that lead reduces the uptake and transportation of some nutrients in plants. Moreover, data (Table 2) showed a significant increase in proline content of shoots of all plants under $\mathrm{Pb}$ and $\mathrm{Zn}$ stress with those of the corresponding controls. On the other hand, cultivation of Zea plant with Lupinus and Hordeum plants caused a marked decrease of proline as compared to treated plants. Evidence suggested that the proline accumulation might contribute to osmotic adjustment at the cellular level and enzyme protection stabilizing the structure of macromolecules and organelles. Increase in proline content may be either due to de novo synthesis or decreased degradation or both (Kasai et al. 1998).

Table1. Effect of $\mathrm{Zn}$ and $\mathrm{Pb}$ on growth and photosynthetic pigment contents of Zea, Lupinus and Hordeum plants.

\begin{tabular}{lcccccc}
\hline Samples & $\begin{array}{c}\text { Shoot dry } \\
\text { wt. (g) }\end{array}$ & $\begin{array}{c}\text { Root dry } \\
\text { wt. (g) }\end{array}$ & $\begin{array}{c}\text { Chlorophyll } \\
\text { a }\end{array}$ & $\begin{array}{c}\text { Chlorophyll } \\
\text { b }\end{array}$ & Carotenoids & $\begin{array}{c}\text { Total } \\
\text { pigments }\end{array}$ \\
\hline Zea & 1.626 & 0.374 & 25.13 & 7.53 & 6.73 & 39.69 \\
Zea treated & 1.370 & 0.296 & 22.85 & 6.47 & 6.33 & 35.65 \\
L.S.D at 5\% & 0.118 & 0.0265 & 1.882 & 0.551 & 0.512 & 2.956 \\
Lupinus & 0.128 & 0.018 & 21.31 & 8.34 & 3.64 & 33.29 \\
Lupinus treated & 0.071 & 0.015 & 17.44 & 5.58 & 2.82 & 25.84 \\
Lupinus treated & 0.092 & 0.016 & 19.76 & 7.09 & 3.11 & 29.96 \\
cultivated with Zea & & & & & & \\
L.S.D at 5\% & 0.0081 & 0.0013 & 1.539 & 0.566 & 0.253 & 2.355 \\
Hordeum & 0.278 & 0.053 & 12.07 & 6.73 & 5.77 & 24.57 \\
Hordeum treated & 0.211 & 0.042 & 8.78 & 3.50 & 4.44 & 16.72 \\
Hordeum treated & 0.254 & 0.048 & 10.42 & 5.83 & 5.03 & 21.28 \\
cultivated with Zea & & & & & & \\
L.S.D at 5\% & 0.0147 & 0.0038 & 0.833 & 0.452 & 0.403 & 1.681 \\
\hline
\end{tabular}

Table 2. Effect of $\mathrm{Zn}$ and $\mathrm{Pb}$ on $\mathrm{Pb}, \mathrm{Zn}$ in shoot and root, total nitrogen and proline contents in shoot of Zea, Lupinus and Hordeum plants.

\begin{tabular}{lcccccc}
\hline Samples & \multicolumn{2}{c}{ Pb } & \multicolumn{2}{c}{ Zn } & Total-N & Proline content \\
& Root & Shoot & Root & Shoot & $\begin{array}{c}\text { mgN/100g } \\
\text { dry wt. }\end{array}$ & $\begin{array}{c}\text { mg/100g } \\
\text { fresh wt. }\end{array}$ \\
\hline Zea & 0.031 & 0.020 & 0.082 & 0.066 & 40 & 9.70 \\
Zea treated & 0.056 & 0.039 & 0.120 & 0.114 & 28 & 35.80 \\
L.S.D at 5\% & 0.0036 & 0.0025 & 0.0081 & 0.0075 & 2.730 & 2.285 \\
Lupinus & 0.015 & 0.013 & 0.053 & 0.044 & 44 & 15.71 \\
Lupinus treated & 0.022 & 0.017 & 0.070 & 0.060 & 32 & 51.50 \\
$\begin{array}{l}\text { Lupinus treated } \\
\text { cultivated with Zea }\end{array}$ & 0.018 & 0.015 & 0.066 & 0.053 & 38 & 36.40 \\
L.S.D at 5\% & 0.0015 & 0.0012 & 0.0050 & 0.0042 & 3.036 & 3.257 \\
$\begin{array}{l}\text { Hordeum } \\
\text { Hordeum treated }\end{array}$ & 0.012 & 0.010 & 0.051 & 0.041 & 80 & 17.90 \\
$\begin{array}{l}\text { Hordeum treated } \\
\text { cultivated with Zea }\end{array}$ & 0.017 & 0.014 & 0.068 & 0.047 & 46 & 75.60 \\
L.S.D at 5\% & 0.014 & 0.011 & 0.062 & 0.043 & 58 & 42.40 \\
\hline
\end{tabular}

Variation in the SDS-PAGE banding pattern of proteins (Table 3) extracted from leaves of $\mathrm{Zea}$, Hordeum and Lupinus plants in response to $\mathrm{Pb}$ and $\mathrm{Zn}$ stress showed the disappearance of 
certain bands and appearance of new bands or increase or decrease in the intensity of other protein bands. The extract of Zea plant was characterized by the presence of 13 common protein bands, molecular weights are; $127.65,123.80,119.64,112.75,102.75,90.88,64.40,59.71,51.71,43.20$, 35.85, 28.09 and $8.9 \mathrm{kDa}$. There were two bands that disappeared in control and appeared with $\mathrm{Pb}$ and Zn stress at molecular weights 108.04 and $74.99 \mathrm{kDa}$. The total number of bands recorded with in the heavy metal treatments were found to be varied; i.e. the highest number (15 bands) was recorded in treated Zea plants, decreased to 13 bands scored in the control Zea plant. The extract of Hordeum plant was characterized by the presence of 11 common protein bands with molecular weights 127.65, 123.80, 119.64, 102.75, 90.88, 74.99, 59.71, 51.71, 43.20, 35.85 and $28.09 \mathrm{kDa}$. Metal stress caused the appearance of 2 protein bands of molecular weights 112.75 and $65.67 \mathrm{kDa}$, and the disappearance of one protein band with molecular weight $64.40 \mathrm{kDa}$. The combination of Hordium with Zea led to appearance of new 3 protein bands at molecular weights 115.1, 56.85 and $18.50 \mathrm{kDa}$ as a defense mechanism for heavy metal stress.

Table 3. Effect of $\mathrm{Zn}$ and $\mathrm{Pb}$ on protein banding patterns of Zea, Lupinus and Hordeum plants.

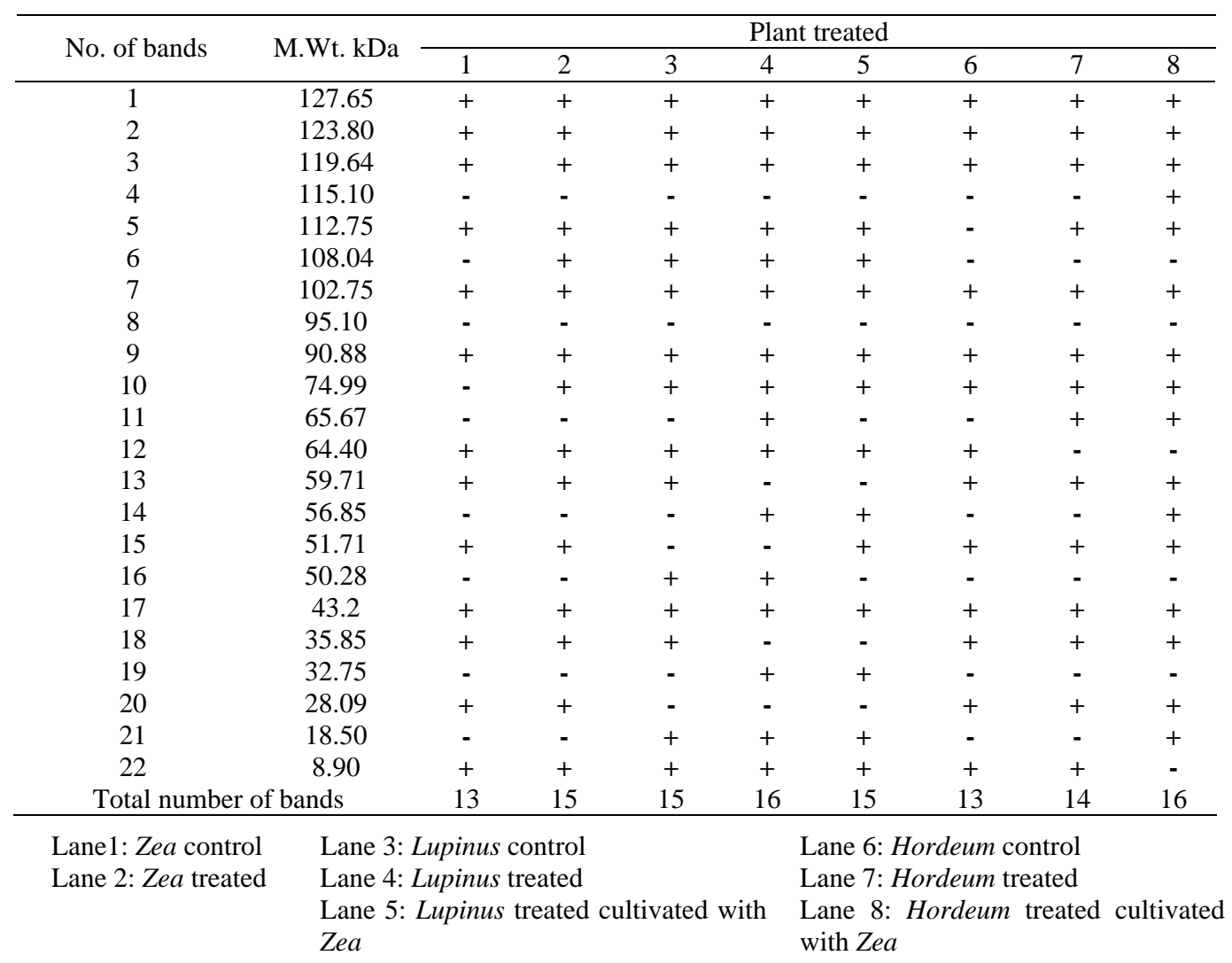

The highest number of bands (16 bands) was recorded in the Hordium treated plants and decreased to 13 bands in the control plant. In the case of Lupinus plant, there were 12 common protein bands with molecular weights 127.65, 123.80, 119.64, 112.75, 108.04, 102.75, 90.88, 74.99, 64.40, 43.20, 18.50 and $8.90 \mathrm{kDa}$. Metal stress induced the appearance of 2 bands with 
molecular weights 56.85 and $32.75 \mathrm{kDa}$, which acts as a defense protein to heavy metal stress, and disappearance of 2 bands whose molecular weights were 59.71 and $35.85 \mathrm{kDa}$. There was one band specific to metal stress only at molecular weight $65.67 \mathrm{kDa}$. There were also another band characterized to metal stress and a combination of Lupinus with Zea plants of molecular weight $51.71 \mathrm{kDa}$. The highest number of bands (16 bands) was recorded in the Lupinus treated plants and decreased to 15 bands in the control plant. The results of SDS-PAGE analysis for soluble proteins demonstrated that metals could affect protein pattern of the quantity of some bands that was changed in polluted plants, meaning that heavy metal stress could affect gene regulation and tend to decrease in some protein bands and increase in the other ones (Yousefi et al. 2011).

\section{References}

AACC 1983. American Association of Cereal Chemists. Methods 26-45 and 46-23. Approved Methods of American Association of Cereal Chemists. The Association. 8th ed. St. Paul, MN.

Bates LE, Waldren RP and Teare I 1973. Rapid determination in free proline of water stress studies. Plant Soil 39: 205-207.

Eun SO, Youn HS and Lee Y 2000. Lead disturbs microtubule organization in the root meristem of Zea mays. Physiologiav Plantarum 110: 357-365.

Fargasova A 2001. Phytotoxic effects of $\mathrm{Cd}, \mathrm{Zn}, \mathrm{Pb}, \mathrm{Cu}$ and $\mathrm{Fe}$ on Sinapsis alba L. seedlings and their accumulation in roots and shoots. Biologia Plantarum 44: 471-473.

Godbold DL and Kettner C 1991a. Lead influences root growth and mineral nutrition of Picea abies seedlings. J. Plant. Physiol. 139: 95-99.

Gosh S 2010. Wetland macrophytes as toxic metal accumulators, Int. J. Environ. Sci. 1(4): 523-528.

Guo TR, Zhang GP and Zhang YH 2007. Physiological changes in barley plants under combined toxicity of aluminum, copper and cadmium. Colloids Surf. B. 57: 182-188.

Hamid N, Bukhari N and jawaid F 2010. Physiological responses of Phaseolus vulgaris to different lead concentrations. Pak. J. Bot., 42: 239-246.

Hassanein RA 1977. Effect of certain growth regulators on plant growth and development. Ph. D. Thesis, Botany Dept., Fac. of Sci., Ain Shams Univ., Cairo Egypt.

Israr M, Jewell A, Kumar D and Sahi SV 2011. Interactive effects of lead, copper, nickel and zinc on growth, metal uptake and antioxidative metabolism of Sesbania drummondii. J. Hazard. Mater. 186: 1520-1526.

January MC, Cutright TJ , Van Keulen H and Wei R 2008. Hydroponic phytoremediation of Cd, Cr, Ni, As and Fe: Can helianthus annuus hyperaccumulate multiple heavy metals?. Chemosphere 70: 531-537.

Kasai Y, Kato M, Aoyama J and Hyodo H 1998. Ethylene production and increase in 1-aminocyclopropane1-carboxylate oxidase activity during senescence of broccoli florets. Acta Hortic. 464: 153-157.

Laemmli UK 1970. Cleavage of structural proteins during the assembly of the head of bacteriophage T4.Nature 227: 680.

Malkowski E, Kita A, Galas W, Karcz W and Kuperberg JM 2002. Lead distribution in corn seedlings (Zea mays L.) and its effect on growth and the concentrations of potassium and calcium. Plant Growth Regul. 37: 69-76.

Metzner H, Rau H and Senger H. 1965. Ultersuchungen Zur synchronisierbarkeit einzelner pigment mangel Mutanten von chlorella. Planta 65: 186-194.

Molgarzata H and Andzej N 2005. Monitoring of Bioremediation of Soil Pollution Applying Bioassays, Electro. J. Polish. Agric. Univ. 8:1-2.

Pereira BFF, Abreu CA, Romeiro S, Lagôa AMM and Paz-González A 2007. Pb-Phytoextraction by maize in a Pb-EDTA treated oxisol. Sci. Agric. (Piracicaba, Braz.) 64(1): 52-60.

Pirie NW 1955. Proteins In: Modern methods of plant analysis (edited by K. Peach and M. V. Tracey) IV: 23 - 58 Springer Verlag, Berlin. 
Prasad KVSK, Pardha Saradhi P and Sharmila P 1999. Concerted action of antioxidant enzymes and curtailed growth under zinc toxicity in Brassica juncea. Environ. Exp. Bot. 42: 1-10.

Saadet S , Muhittin D and Gonca K 2004. Effect of lead and pH on lead Uptake, chlorophyll and nitrogen content of Typha latifolia L. and Ceratophyllum demersum L. Int. J. Agri. Biol. 6(1): 168-172.

SAS- Programme 1982. SAS user’s Guide Statistics SAS Institute, INC, Raleiegh. NC, pp. 584.

Saygideger S , Dogan M and Keser G 2004. Effect of lead and pH on lead uptake, chlorophyll and nitrogen content of Typha latifolia K. and Ceratophyllum demersum L. Int. J. Agri. Biol. 6(1): 168-172.

Sharma P and Dubey RS 2005. Lead toxicity in plants. Braz. J. Plant Physiol. 17: 35-52.

Siedlecka A and Krupa Z 1996. Interaction between cadmium and iron and its effects on photosynthetic capacity of primary leaves of Phaseolus vulgaris. Plant Physiol. Biochem. 34: 833-841.

Sivasankar R, Kalaikandhan R. Vijayarengan, P. 2012. Phytoremediating capability of four plant species under zinc stress. Intern. J. Environ. Sci. Tech. 2(1): 1-9.

Studier FW 1973. Analysis of bacteriophage T7 early RNAs and proteins on slab gels. J. Mol. Biol. 79: 237-248.

Vaillant N, Monnet F, Hitmi A , Salanon H and Coudret A 2005. Comparative study of responses in four Datura species to a zinc stress. Chemosphere, 59: 1005-1013.

Visoottiviseth P, Francesconi K, and Sridokchan W 2002. The potential of Thai indigenous plant species for the phytoremediation of arsenic contaminated land. Environmental Pollution. 118: 453-461.

Wright RT 2007. Environmental Science: Toward a Sustainable Future. 9th Ed Prentice Hall of India, New Delhi.

Yousefi N, Chehregani A, Malayeri B, Lorestani B and Cheraghi M 2011. Effect of the heavy metals on the developmental stages of ovule and seed proteins in Chenopodium botrys L. (Chenopodiaceae). Biol. Trace Elem. Res. 144: 1142-1149.

Zeng-Bin Luo, Xiao-Jia He, Lin Chen, Lin Tang, Shun Gao and Fang Chen 2010. Effects of zinc on growth and antioxidant responses in Jatropha curcas seedlings. Int. J. Agric. Biol. 12(1 : 119-124. 